\title{
Detection of Proteinuria by Colorimetric Method and Correlation with Disease Severity in Patients Dengue
}

\author{
Acivrida Mega Charisma, Elis Anita Farida, Farida Anwari \\ Medical Laboratory Technology, Stikes Anwar Medika Hospital, Sidoarjo, Indonesia. E-mail: acie.vrida@gmail.com
}

\begin{abstract}
Severe dengue virus infection often causes proteinuria through several mechanisms, such as leakage of plasma proteins caused by higher protein filtering in the kidneys. The condition of proteinuria in patients with dengue shock syndrome will affect the management, prognosis, and mortality of patients with dengue virus infection. The objectives of this study were to determine the presence of protein in urine samples in patients in which IgG/IgM dengue was detected, to determine the presence of protein in urine samples in patients without dengue infection, and to determine the relationship between proteinuria in dengue patients and the degree of disease severity. The study was conducted in March-June 2020 at the Clinical Laboratory and Inpatient Clinic of Vita Medika Kepung, Kediri Regency. The method used was the consecutive sampling technique. The minimum sample size was 100 respondents with criteria for suspected dengue infection, onset fever $>4$ days, age $>2$ years, and no indication of other infectious diseases (blood and urine), divided into two groups, group with positive dengue infection and non-dengue group. The results showed that proteinuria was detected in $26 \%$ of respondents, secondary dengue infection and positive serological test of IgG, IgM only IgG were detected in 24 (92.3\%) respondents and positive IgG and IgM were found in $2(7.7 \%)$ respondents, this was shown by the $p$-value $=0.000$ in the Chi-Square test with a Prevalence Ratio (PR) value of 11,987. In addition, Chi-Square test results indicated that a higher urine protein/albumin led to more severe disease, with $p$-value $=0.012$ and $0.025(p<0.05)$ and PR values of 3.333 and 2.800 . The results of this study concluded that there was a close relationship between high levels of protein/albumin in the urine with the degree of disease severity in patients with dengue infection. In addition, an increase in urine protein/albumin levels is always followed by a decrease in serum protein/albumin levels.
\end{abstract}

Keywords: Dengue hemorrhagic fever, proteinuria, severity, colorimetry

\section{INTRODUCTION}

Dengue Fever (DF) and Dengue Hemorrhagic Fever (DHF) are infectious diseases caused by the dengue virus, which is transmitted through the Aedes aegypti and Aedes albopictus mosquitoes. This disease frequently causes extraordinary events (KLB) in Indonesia. Based on data from the Kediri District Health Office, there was an increased morbidity rate of DHF in Sidoarjo district from 8.12 per 100,000 population in 2014 to 28.3 per 100,000 population in 2015.

The clinical manifestations of dengue hemorrhagic fever highly vary. Apart from the complex pathogenesis and differences in virus serotypes in different regions, predicting patients who experience repeated shock or shock will be challenging. Therefore, indicators are needed for dengue hemorrhagic fever patients to predict the occurrence of shock. It may be associated with coinfections, comorbidities, or complications of prolonged shock. ${ }^{1}$ Severe dengue virus infection often causes proteinuria because the higher amount of protein is filtered by the kidneys, resulting in plasma protein leakage. Therefore, low protein or albumin levels are indicated by damage and the leakage of the endothelium of blood vessels, and albumin levels are used as an indicator of plasma leakage and a prognostic marker. ${ }^{2}$

Research on proteinuria is crucial because it can determine the type of colloid fluid used if the size of the type of protein excreted can be determined. This research is consistent with the study reporting a $15 \%$ incidence of proteinuria in dengue virus infection and $27 \%$ of proteinuria in dengue hemorrhagic fever. ${ }^{2}$ Accurate information regarding the grading of severity in dengue patients is essential because it determines the necessary medical treatment. However, the disease severity is monitored through clinical examination and blood tests. In fact, in certain conditions, blood sampling is complex.

The samples used in this study were blood and urine, the same as in previous studies. However, the previous research focused on the detection of 
dengue IgG in urine samples. In contrast, urine samples were used in this study to detect the presence of protein in the urine of patients with suspected dengue and followed with complete blood count and dengue rapid IgG/IgM serology and related it to the grading of severity of the patient's dengue infection.

\section{METHODS}

This research was conducted in March-June 2020 using a cross-sectional research design and consecutive sampling in laboratory installations, emergency rooms, Outpatient and Inpatient Clinics in Vita Medika, Karangdinoyo, Kepong, Kediri Regency. The study subjects consisted of patients with fever symptoms $>4$ days (all gender aged $>2$ years) according to the WHO criteria and no indication of other infectious diseases such as urinary tract infections, throat, typhoid fever. The severity of dengue disease in this study was divided into four degrees: Grade I with signs of fever accompanied by typical clinical symptoms and the only manifestation of bleeding in a positive tourniquet test, hemoconcentration thrombocytopenia; Grade II with characters similar to Grade I accompanied by spontaneous bleeding on the skin or other are; Grade III with circulatory failure characterized by fast/slow pulse, hypotension, cold and restless skin and the heaviest; Grade IV was characterized by circulatory collapse, unpalpable pulse, and unmeasured blood pressure. The number of samples required was calculated using the slovin formula $\mathrm{n}=\mathrm{N} /\left(1+\left(\mathrm{N} \times \mathrm{e}^{2}\right)\right), \mathrm{N}$ is the population: 150 , e: margin of error is $5 \%(0.05)$, with a confidence interval of $95 \%$. The number of samples ( $n$ ): 100 were obtained. Blood and urine were taken simultaneously and used as the sample in this study. The exclusion criteria in this study were patients with suspected dengue aged $<2$ years and heat onset $<4$ days with incomplete medical records. The patient was unwilling to be a respondent in the study, and other infectious diseases such as urinary tract and throat typhoid fever were detected. This research has obtained ethical eligibility permission from STIKES Anwar Medika Hospital with number 638/RSAM/VII/2020.

The laboratory test in this study was carried out at the Vita Medika Inpatient Clinic Laboratory Installation. The instruments used in this study were plain blood tubes, centrifuge tubes, urine pots, IgG/IgM dengue brand Answer IgG, IgM ComboRapid Test produced by CTK Biotech, Inc. Urine analyzer unit-50 produced by Unit Medica Electronic, Co., Ltd., China with the Ministry of Health number AKL 20101802028, microlab 300 Lx produced by Elite Group Vital Scientific, Urine Stick brand Unit $11 \mathrm{G}$ (special reagent for urit-50), total protein reagent kit (biuret colorimetric), albumin reagent kit (BCG colorimetric) brand Diasys. Data were processed and analyzed using tables. The relationship between proteinuria and the grade of dengue infection was determined using Chi-Square statistical test on SPSS ver 16.0, and p-value $<0.05$ was considered significant.

\section{RESULTS AND DISCUSSIONS}

The results showed that out of 100 respondents, 79 (79.0\%) of respondents had a Grade I severity level. This grade was more dominant than Grades II and III. The clinical symptoms at Grade I are sudden high fever for several days, headache, muscle-orbital pain, myalgia, skin rash, and positive RL test, which

Table 1. Characteristics of subjects

\begin{tabular}{cllll}
\hline \multirow{2}{*}{ Variables } & \multicolumn{3}{c}{ Disease Severity (n,\%) } & \multirow{2}{*}{ Total } \\
\cline { 2 - 4 } & I & II & III & \\
\hline Age (years): & $31(39.3)$ & $1(6,6)$ & $1(16.7)$ & $33(33)$ \\
$1-10$ & $25(31.6)$ & $0(0)$ & $1(16.7)$ & $26(26)$ \\
$11-20$ & $14(17.7)$ & $4(26.7)$ & $2(33.3)$ & $20(20)$ \\
$21-30$ & $7(8.9)$ & $4(26.7)$ & $2(33.3)$ & $13(13)$ \\
$31-40$ & $2(2.5)$ & $6(40)$ & $0(0)$ & $8(8)$ \\
$>40$ & $79(100)$ & $15(100)$ & $6(100)$ & $100(100)$ \\
Total & & & & \\
Gender: & $34(43)$ & $6(40)$ & $2(20)$ & $42(42)$ \\
Male & $45(57)$ & $9(60)$ & $4(80)$ & $58(58)$ \\
Female & $79(100)$ & $15(100)$ & $6(100)$ & $100(100)$ \\
Total & & & & \\
\hline
\end{tabular}


was different from Grade II characterized by spontaneous bleeding in the skin while Grade III was present. The most visible signs of impaired circulation are hypotension and skin that is moist and cold. After entering the human body, the dengue virus will replicate and release substances that damage blood vessel cells. This process causes the increased permeability of the capillary walls, marked by the widening pores of the capillary blood vessels, which causes the leakage of platelets and erythrocytes. ${ }^{1}$

The results in Table 1 showed that most subjects (33 respondents, 33\%) in this study were pediatric respondents aged 1-10 years, are at Grade I was found in 31 respondents (39.3\%), and are more are at Grade II was found in adult respondents ( $>40$ years) with the percentage of $40 \%$. Imperfect immune factors cause dengue cases in children compared to adults. Therefore, children have a higher risk of diseases, including diseases caused by the dengue virus. ${ }^{2}$ Contrastingly, Grade II and III were dominated by adult respondents ( $>40$ years) compared to children and adolescents. The results of this study were supported by the statement of the Caribbean Epidemiology Center in 2000, suggesting that the patients who suffer from DHF were children and adults. Age is one factor that affects sensitivity to dengue virus infection and has a vital role in the emergence of plasma leakage as the clinical symptom. ${ }^{2}$ Based on gender, it was shown that male respondents dominated patients with dengue fever Grading I, II, and III as many as 45 (57\%), 9 (60\%), and $4(80 \%)$ showing that the number of dengue cases in males was more dominant than in females with a ratio of $1.6: 1.9(60 \%)$ and $4(80 \%)$. The number of dengue cases in males was more prevalent than in females, with a ratio of 1.6:1.

The results of the IgM and Ig $\mathrm{G}$ dengue rapid tests in Table 2 showed that only six respondents (6\%) had positive IgM and IgG, eight respondents (8\%) were both positive IgM and IgG, and only eight dengue IgG was positive among all respondents. Seventy respondents $(70 \%)$ and negative dengue IgM and
Table 2. Results of dengue rapid IgM and IgG tests

\begin{tabular}{lcc}
\hline Check-up Result & Total & Percentage \\
\hline IgM/IgG dengue rapid test & $(\mathrm{n})$ & $(\%)$ \\
IgM (+), IgG (-) & 6 & 6 \\
IgM (-), IgG (+) & 70 & 70 \\
IgM (+), IgG (+) & 8 & 8 \\
IgM (-), IgG (-) & 16 & 16 \\
Total & 100 & 100 \\
\hline
\end{tabular}

IgG were found in 16 respondents (16.0\%). Respondents whose negative IgM and IgG results showed symptoms that arose due to other infections (non-dengue) or antibodies had not been formed and a second serological test was needed in the healing phase to see the possibility of change of negative IgG to positive results. In the serological test of dengue diagnosis, the sampling time greatly affects the results because dengue antigen or antibody in the body has a unique period. The length of fever is generally used as the standard for determining the time of blood sampling to diagnose dengue. Errors in timing the test can result in false-negative results. Day 3-5 fever is the best time to perform a serological test because antibody formation has begun to be found. ${ }^{4}$ On days 0-2 of fever, the patient is still in the febrile phase, at which the laboratory instruments can detect no hemodynamic changes and antibody formation. However, respondents with positive IgM and IgG results were suspected of secondary infection because it was necessary to examine dengue IgM and Ig $G$ with the ELISA method to determine the type of infection and the IgM/IgG ratio. Ig M/IgG ratio of $<0.9$ can be used as a predictor of secondary disease.

The results of urine examination in Table 3 were obtained from 100 respondents; 26 respondents (26.0\%) detected semi-quantitative proteinuria with positive criteria 1 , positive 2 , and positive 3 . Urine albumin test showed proteinuria positive 1 , positive 2 , and positive 3 with an average level of $0.048 \mathrm{~g} / \mathrm{dL}$; $0.107 \mathrm{~g} / \mathrm{dL}$; and $0.152 \mathrm{~g} / \mathrm{dL}$, respectively. In addition, total urine protein test showed proteinuria positive 1 ,

Table 3. Results of measurement of albumin and protein levels in urine and serum sample with positive proteinuria

\begin{tabular}{llccc}
\hline \multirow{2}{*}{ Sample Type } & \multirow{2}{*}{ Examination } & \multicolumn{3}{c}{ Average Levels $(\mathbf{g} / \mathbf{d L})$} \\
\cline { 3 - 5 } & & Positive 1 & Positive 2 & Positive 3 \\
\hline \multirow{2}{*}{ Urine } & Albumin $(\mathrm{g} / \mathrm{dL})$ & 0.048 & 0.107 & 0.152 \\
& Total protein $(\mathrm{g} / \mathrm{dL})$ & 0.173 & 0.225 & 0.33 \\
\multirow{2}{*}{ Serum } & Albumin $(\mathrm{g} / \mathrm{dL})$ & 3.368 & 3.139 & 3.083 \\
& Total protein $(\mathrm{g} / \mathrm{dL})$ & 5.518 & 5.167 & 4.633 \\
\hline
\end{tabular}


positive 2, positive 3 with an average level of 0.173 $\mathrm{g} / \mathrm{dL} ; 0.225 \mathrm{~g} / \mathrm{dL}$; and $0.33 \mathrm{~g} / \mathrm{dL}$, respectively. This finding indicated an increase in albumin levels in the urine at any time because it is evaluated from the normal limit value when urine albumin is $<0.08 \mathrm{~g} / \mathrm{L}$ or $<0.008 \mathrm{~g} / \mathrm{dL}$. Based on the results of serology test Table 3, it was found that the average albumin level with proteinuria was positive 1 , positive 2 , and positive 3 at $3.368 \mathrm{~g} / \mathrm{dL} ; 3.139 \mathrm{~g} / \mathrm{dL}$; and $3,083 \mathrm{~g} / \mathrm{dL}$, which showed a decrease. Therefore, it was concluded that a urine albumin level was inversely proportional to serum albumin in respondents with positive proteinuria. A higher albumin level in the urine led to a lower albumin level in the serum. This phenomenon also applies to the total protein test because albumin is the largest total protein fraction. A decrease or increase in albumin levels will directly and significantly affect total protein levels. ${ }^{4}$

The data in Table 4 shows that 24 (92.3\%) respondents with detected proteinuria had positive dengue IgG serology results (secondary infection). The remaining $2(7.7 \%)$ had positive IgM and IgG tests (suspected secondary infection), and there were no respondents with proteinuria who had positive IgM serology tests (primary infection).

The Chi-Square test results obtained a PR value of 11,987, suggesting that respondents with proteinuria had an 11,987x greater risk of positive dengue Ig $G$ serologic test (secondary infection) than those with positive dengue IgG serologic with a positive IgM and IgG serology results simultaneously (suspected secondary infection). The p-value obtained was $0.000(p<0.05)$, indicating a close and positive relationship between the results of positive dengue IgG serology and proteinuria. Dengue fever had a significant increase in urine protein levels compared to patients with dengue virus infection. The average increase in proteinuria was experienced two days before or three days after the fever fell (convalescence phase). The rise in proteinuria levels occurred after detecting dengue IgG that appeared after the fever dropped starting from the onset of fever. ${ }^{4}$

The statistical results of the Chi-Square test mean albumin and urine protein levels with the grade of disease severity obtained prevalent ratio $=3.333$, which indicates that respondents with Grade I severity had a 3.333 times greater risk of positive proteinuria I. Then respondents with a grade of severity level II has a 2.8 times greater risk of positive proteinuria two and the $p$-value results obtained were 0.012 and $0.025(p<0.05)$, indicating $a$ significant relationship between the grade of disease severity and the level of proteinuria detected from urine examination in patients with dengue fever. There was a $15 \%$ incidence of proteinuria in dengue virus infection with $27 \%$ of proteinuria in dengue fever. ${ }^{5,6}$ Proteinuria in dengue fever occurs due to the glomerulonephritis process by the immune complexes in the blood vessels, which causes vasculitis. The peak levels of proteinuria occur due to an autoimmune process in which the dengue virus

Tabel 4. The relationship between proteinuria and serological results of IgM and IgG dengue rapid tests

\begin{tabular}{|c|c|c|c|c|c|}
\hline \multirow[b]{2}{*}{ Rapid Test Result } & \multicolumn{2}{|c|}{ Proteinuria } & \multirow[b]{2}{*}{ Total } & \multirow[b]{2}{*}{ p-value } & \multirow[b]{2}{*}{ PR } \\
\hline & Negative & Positive & & & \\
\hline IgM, IgG dengue & $n(\%)$ & $\mathrm{n}(\%)$ & n (\%) & & (CI 95\%) \\
\hline $\operatorname{IgG}(+)$ & $0(0.0)$ & $24(92.3)$ & $24(100.0)$ & 0.000 & 11.987 \\
\hline $\operatorname{IgM}, \operatorname{IgG}(+)$ & $0(0.0)$ & $2(7.70)$ & $2(100.0)$ & & \\
\hline Total & $0(0.0)$ & $26(100.0)$ & $26(100.0)$ & & \\
\hline
\end{tabular}

Note: CI (Confident Interval)

Tabel 5. Relationship between average albumin levels and total urine protein with the grade of disease severity

\begin{tabular}{|c|c|c|c|c|c|c|}
\hline \multirow{2}{*}{ Degree of Severity } & \multicolumn{3}{|c|}{ Mean Urine Albumin/Total Protein Levels (g/dL) } & \multirow{2}{*}{ Total } & \multirow{2}{*}{ Value } & \multirow{2}{*}{ PR } \\
\hline & Pos. 1 & Pos. 2 & Pos. 3 & & & \\
\hline Disease & $0.048 / 1.736$ & $0.107 / 2.25$ & $0.485 / 3.30$ & n (\%) & $p$ & \\
\hline I & $12(100.0)$ & $0(0.0)$ & $0(0.0)$ & $12(100.0)$ & & \\
\hline II & $3(30.0)$ & $7(70.0)$ & $0(0.0)$ & $10(100.0)$ & 0.012 & 3.333 \\
\hline Total & $\begin{array}{l}0(0.0) \\
15(57.7)\end{array}$ & $\begin{array}{l}1(25.0) \\
8(30.8)\end{array}$ & $\begin{array}{c}3(75.0) \\
3(11.5)\end{array}$ & $\begin{array}{l}4(100.0) \\
26(100.0)\end{array}$ & 0.025 & 2.800 \\
\hline
\end{tabular}


activates the reticuloendothelial system in the glomerulus, causing leakage due to inflammation. Research by experts shows that serum electrolyte disturbances such as mild hyponatremia can differentiate the severity of dengue virus infection. The enzyme markers secreted by the liver from the mean levels of AST and ALT enzymes show a significant difference between DHF II and Grade IV. ${ }^{6}$ In addition to features of abnormalities in serum, can evaluate the differences that occur in urine in patients with dengue virus infection because the kidneys suffer minor injuries due to this viral infection. ${ }^{6}$ Patients with dengue shock syndrome excrete smaller proteins as indicated by the increased excretion of hepatic sulfate in patients with dengue accompanied by shock. ${ }^{6}$ Proteinuria and hematuria in dengue patients occur due to kidney injury or damage to the renal glomerulus. This damage occurs due to secondary processes of the complex immune system that are deposited with viral antigens. There is the mesangial proliferation of deposition of IgG, IgM, C3, and thickening of the glomerular membrane. These immune complexes are usually excreted in urine because the size of the particles is smaller than the diameter of the renal glomerulus. ${ }^{1}$

Dengue shock syndrome is a condition of circulatory failure due to dengue virus infection characterized by weak pulse, tachycardia, narrow pulse pressure, hypotension (disease severity III), and severe shock (Grade IV) that pulse and blood pressure are not measured. 'The pathophysiology, hemodynamics, and biochemistry of dengue are not known with certainty. Most of the pathophysiology still adheres to the secondary heterogeneous infection hypothesis. Dengue hemorrhagic fever infection can occur when someone is infected with the dengue virus for the first time and gets a second infection with a different serotype of the dengue virus within six months to 5 years. In this condition, it is known as antibody-dependent enhancement, when the antibodies that are initially formed by primary infection react with other viral antigens to form complexes that bind to cell receptors that cause the virus to infect cells. However, many other risk factors cause disease severity apart from secondary infection, such as nutritional status, gender, age, immune status, viral strain malignancy, etc. Primary or secondary dengue infection status should be predicted as a precautionary measure against the possibility of an increase in the degree of severity in patients with dengue infection. ${ }^{7}$ One of the laboratory parameters that can be used to predict this possibility is the serological test of dengue IgG and IgM. In some conditions, a ratio of IgG/IgM $>0.9$ can be used as a predictor of secondary infection in dengue infection or IgM/IgG $<1.8$ quantitatively by using the ELISA method. ${ }^{4}$

\section{CONCLUSIONS AND SUGGESTIONS}

This research concludes that there was a significant relationship between protein or albumin levels in the urine and the severity of dengue fever. A higher urine protein or albumin levels led to a greater degree of severity. In addition, higher protein or albumin levels in the urine led to lower protein or albumin levels in serum.

\section{REFERENCES}

1. Adissadah AF, Aryati, Pusarwati S. Prevalence of expanded dengue syndrome in patients with dengue virus infection at the Dr. Soetomo Hospital Surabaya in 2017-2018. Indonesian Journal of Clinical Pathology and Medical Laboratory, 2020; 26(03): 307-311.

2. Charisma AM. Gambaran jumlah trombosit dan nilai hematrokit pada pasien Demam Berdarah Dengue (DBD) yang cenderung mengalami komplikasi shock di RSU Anwar Medika periode Februari-Desember 2016. Jurnal Sainmed, 2020; 09(02): 83-88.

3. Lidya Trisnadewi, Ni Nyoman Wande. Pola serologi IgM dan IgG pada infeksi Demam Berdarah (DBD) di Rumah Sakit Umum Pusat Sanglah, Denpasar, Bali bulan Agustus Sampai September 2014. E-Journal Med. 2016; 5(8): 1-5.

4. Charisma AM, Farisa EA, Anwari F. Diagnosis dengue melalui deteksi antibodi Imunoglobulin $G$ spesifik dalam sampel urine dengan Teknik ELISA. Aspirator, 2020; 12(01): 11-18.

5. Andries AC, Duong V, Cappelle J. Proteinuria during dengue fever in children. International Journal of Infection Diseases, 2017; 55(01): 38-44.

6. Saudo RM, Rampengan NH, Mandei JM. Gambaran hasil pemeriksaan fungsi hati pada anak dengan infeksi dengue periode Januari 2011-Oktober 2016 di RSUP Prof. Dr. R. D. Kandou Manado. Jurnal E-Clinic, 2016; 04(02): 64-69.

7. Bagus N. Rasio IgM/IgG fase akut untuk menentukan infeksi dengue sekunder. Sari Pediatri, 2016; 8(1): 2. 